\title{
Digestibility, fermentation and microbiological characteristics of Calotropis procera silage with different quantities of grape pomace
}

\author{
Digestibilidade, características fermentativas e microbiológicas da silagem de \\ flor-de-seda com diferentes níveis de resíduo de uva
}

\author{
Clérison dos Santos Belém¹, Anderson Miranda de Souza', Patrícia Rodrigues de Lima', \\ Francisco Allan Leandro de Carvalho' ${ }^{1}$, Mário Adriano Ávila Queiroz ${ }^{1 *}$, Mateus Matiuzzi da Costa $^{1}$
}

\author{
'Universidade Federal do Vale do São Francisco/UNIVASF, Petrolina, PE, Brasil \\ *Corresponding author: marioqueiroz@hotmail.com \\ Received in May 17, 2016 and approved in August 8, 2016
}

\begin{abstract}
Preserving forage plants adapted to a semi-arid climate as silage may minimize the animal feed deficit during drought. The objective of this study was to evaluate the effects of different quantities of grape pomace added to Calotropis procera silage on its fermentation, in vitro digestibility, total digestible nutrients and microbiology. A completely randomized experimental design was used with four treatments $(0$, 10, 20 and 40\% fresh matter) and four replicates. The silos were opened after 90 days of ensilage, and the soluble carbohydrate, ethanol, organic acid and ammoniacal nitrogen concentrations; $\mathrm{pH}$; fermentation loss; dry matter (DM) recovery; DM density, and microbial populations were determined. The $\mathrm{pH}$ (3.96-3.87) was adequate for ensiling in all silage samples. The soluble carbohydrate concentration decreased $(p<0.05)$, and the ethanol concentration increased with increasing quantities of grape pomace. The lactic acid concentration decreased $(p<0.05)$ from 5.3 to $1.94 \% \mathrm{DM}$, and the acetic, propionic and butyric acid concentrations increased with increasing quantities of grape pomace. The lactic acid bacteria decreased linearly $(p<0.05)$, varying from 6.43 to $5.82 \mathrm{log}$ CFU/g silage. The mold and yeast population variations fit best using a third-order polynomial equation $(p<0.05)$. Enterobacteria and Clostridium spp were not observed. Adding grape pomace to the silage increased the effluent and gas loss; the latter varied from 5.35 to $14.4 \%$. The total digestible nutrient (TDN) variation fit best using a second-order polynomial equation, and the maximum value was estimated at $82.95 \%$ DM with $3.5 \%$ grape pomace using the regression equation. The percent digestibility decreased linearly $(p<0.05)$ with increasing quantities of grape pomace. We show that Calotropis procera has potential as silage even without adding grape pomace.
\end{abstract}

Index terms: Fermentation losses; microorganisms; organic acids.

\begin{abstract}
RESUMO
A conservação de plantas forrageiras adaptadas ao clima Semiárido na forma de silagem pode minimizar o déficit alimentar dos animais nos períodos de estiagem. Nesse contexto, objetivou-se avaliar os efeitos de níveis de inclusão de resíduo de uva na dinâmica fermentativa, na digestibilidade in vitro, nos nutrientes digestíveis totais e na microbiologia da silagem de flor-de-seda (Calotropis procera). Em delineamento inteiramente casualizado com quatro tratamentos (0,10,20 e 40\% na matéria natural) e quatro repetições. Após 90 dias os silos foram abertos, e foram determinados os teores de carboidratos solúveis, etanol, ácidos orgânicos, pH e nitrogênio amoniacal, perdas fermentativas, recuperação da MS e densidade, populações microbianas. Em todas as silagens o $\mathrm{pH}$ encontrado mostrou-se adequado ao processo de ensilagem (variação de 3,96 a 3,87). À medida que aumentou os níveis de resíduo de uva foi verificado redução $(P<0,05)$ nos teores de carboidratos solúveis e aumento nos valores de etanol. Houve reduções $(P<0,05)$ nos teores de ácido lático de 5,3 a 1,94\% da MS e aumento nos teores de acético, propiônico e butírico com o aumento do resíduo de uva. As bactérias produtoras de ácido lático apresentaram redução linear $(P<0,05)$ e variando de 6,43 a 5,82 log UFC/g de silagem, os fungos e leveduras apresentaram efeito cúbico ( $P<0,05)$, não foram encontradas enterobactérias e Clostridium spp. Com adição do resíduo de uva houve aumento nas perdas por efluentes e nas perdas por gases variaram de 5,35 a 14,4\%. Observou-se efeito quadrático para nutrientes digestíveis totais (NDT) sendo estimado a partir da equação de regressão seu valor máximo de $82,95 \%$ na MS ao nível de inclusão de $3,5 \%$ de resíduo de uva e redução linear $(P<0,05)$ no percentual de digestibilidade. A silagem de flor-de-seda apresentou potencial para conservação na forma de silagem, não havendo necessidade de utilização de resíduo de uva.
\end{abstract}

Termos para indexação: Perdas de fermentação; microorganismos; ácidos orgânicos.

\section{INTRODUCTION}

Calotropis procera is an evergreen plant species adapted to the edaphoclimatic conditions of the Brazilian semiarid region and can be used as animal feed (Costa et al., 2009).
Despite its availability and potential as forage resource, $C$. procera features certain nutritional limitations with antinutrition factors in its composition, such as flavonoid and cardiotonic glycosides. However, chopping and drying may result in loss and volatilization of certain 
such compounds, enabling its consumption by animals (Mello et al., 2001).

Due to its high availability and desirable chemical and bromatological composition, C. procera may be a viable forage alternative, which may improve the use of available forage resources in the Brazilian semi-arid region. However, little is known about ensiling C. procera, and no studies have quantified its fermentation loss, alcohol production, soluble carbohydrate, organic acids, and microbial populations.

Another forage alternative is grape pomace from wine and sparkling wine production; grape pumice is abundant in the wine-producing regions of São Francisco Valley, especially in the irrigation district of Juazeiro (state of Bahia-BA) and Petrolina (state of Pernambuco-PE). A portion of this residue is used for vineyard fertilization, and the remainder is discarded. Using grape pomace is a means for recycling its nutrients and may be important in decreasing production costs. Grape pomace may be used as animal feed for herds in the São Francisco Valley Hinterlands (Barroso, 2006).

Combining C. procera with grape pomace may improve the silage characteristics through increasing the silage dry matter (DM) concentrations, enriching the silage with nutrients that were not extracted during wine production and reusing residues from the region's agroindustries.

The objective of this study is to evaluate the effects of adding different levels of grape pomace $(0$, 10, 20 and $40 \%$ ) to wilted $C$. procera ensilage on the silage's fermentation pattern, microbial populations and digestibility.

\section{MATERIAL AND METHODS}

The experiment was conducted at the Agricultural Sciences campus of the Federal University of São Francisco Valley (Universidade Federal do Vale do São Francisco - Univasf) in the municipality of Petrolina, PE located at $9^{\circ} 09^{\prime} \mathrm{S}$ latitude and $40^{\circ} 22^{\prime}$ 'W longitude with a 365-m mean altitude and 400-mm mean annual rainfall. A completely randomized experimental design was used with four treatments (grape pomace levels: 0, 10, 20 and $40 \%$ ) and four replicates.

Sixteen silos were used for silage production. The silos consisted of 25-liter plastic buckets containing 2 $\mathrm{kg}$ of dry sand at the bottom overlaid with a thin plastic sheet and cotton fabric and lids with Bunsen valves for gas release and gravimetric gas measurement.
The forage plant used was $C$. procera. Plants of an undetermined age were harvested manually at the Petrolina irrigation district (PE). Plants without woody stems and between 0.2- and 1.6-m high were harvested. The plants were chopped using a stationary chopper into particles varying between 2 and $3 \mathrm{~cm}$ in size. Due to its low DM content $(13 \%)$, the material wilted for 22 hours in open air until reaching $25 \% \mathrm{DM}$.

The grape pomace originated from wine production using Syrah grapes containing $50.67 \%$ DM. C. procera was replaced with $0,10,20$ and $40 \%$ grape pomace and compacted by stamping. The silos were immediately sealed using adhesive tape, weighed to determine loss and density and stored at room temperature.

After 90 days of ensilage, the silos were weighed and opened, and samples were collected. The empty set (silo, lid, plastic sheet, sand and cotton fabric) was weighed to quantify effluent production, gas loss and total DM loss using the following equations (Jobim et al., 2007) (Equations 1, 2, 3 and 4).

$\mathrm{EP}=[($ Wop - Wen $) / \mathrm{GF}] \times 1000$

$\mathrm{EP}=$ effluent production $(\mathrm{kg} / \mathrm{t}$ green forage $) ;$ Wop $=$ weight of the set (silo + sand + plastic + fabric) at silo opening $(\mathrm{kg})$; Wen $=$ weight of the set $($ silo + sand + plastic + fabric) at ensiling ( $\mathrm{kg})$; and $\mathrm{GF}=$ green forage ensiled ( $\mathrm{kg})$.

$\mathrm{GL}=[($ WSen - WSop $) /$ WFen $\times$ DMf $] \times 100$

$\mathrm{GL}=$ gas loss during ensiling $(\%$ initial DM $)$; WSen $=$ silo weight at ensiling ( $\mathrm{kg}$ fresh matter); WSop = silo weight at opening ( $\mathrm{kg}$ fresh matter); WFen = forage weight at ensiling ( $\mathrm{kg}$ fresh matter); and $\mathrm{DMf}=$ forage $\mathrm{DM}$ content at ensiling (\%).

$\mathrm{DMR}=[(\mathrm{FWop} \times \mathrm{DMop}) /(\mathrm{FWcl} \times \mathrm{DMcl})] \times 100$

$\mathrm{DMR}=$ dry matter recovery rate $(\%) ; \mathrm{FWop}=$ forage weight at silo opening $(\mathrm{kg})$; DMop $=\mathrm{DM}$ content at silo opening $(\%) ; \mathrm{FWcl}=$ forage weight at silo closing $(\mathrm{kg})$; and $\mathrm{DMcl}=$ forage $\mathrm{DM}$ content at silo closing $(\%)$.

$\mathrm{DML}=[(\mathrm{DMi}-\mathrm{DMf}) / \mathrm{DMi}] \times 100$

$\mathrm{DML}=$ total DM loss; $\mathrm{DMi}=$ initial DM (silo weight after filling - weight of the empty set before filling (dry tare) $\mathrm{x}$ forage $\mathrm{DM}$ concentration at ensiling); and $\mathrm{DMf}=$ final DM content (silo weight). 
The silage density was calculated as the ratio between the ensiled green forage and silo volume $(\mathrm{kg}$ GF.m $\left.{ }^{3}\right)$. The ammoniacal nitrogen $\left(\mathrm{N}-\mathrm{NH}_{3}\right)$ and $\mathrm{pH}$ were quantified in accordance with Silva and Queiroz (2002).

The silage extracts were obtained using a 15ton hydraulic press and used determine the ethanol, soluble carbohydrate and organic acid concentrations. The ethanol and lactic, acetic, propionic and butyric acid concentrations were quantified using gas chromatography with a Thermo Scientific ${ }^{\circledR}$ chromatograph equipped with a flame ionization detector and automated sample injection (Palmquist; Conrad, 1971). The lactic acid concentrations were determined using high performance liquid chromatography (HPLC) (Schmidt et al., 2007), and the soluble carbohydrate concentrations were determined in accordance with Dubois et al. (1956).

The microbiological analyses were performed in accordance with Jobim et al. (2007). The microbial counts were performed using selective culture media for each microbial group: Rogosa Agar (Difco) for lactic acid bacteria (LAB), Violet Red Bile (Difco) for enterobacteria (ENT), Potato Dextrose Agar (Difco) acidified with tartaric acid for mold and yeasts (MY), and Reinforced Clostridial Medium (RCM) for Clostridium spp. (CL).

To count the microbial groups, 10 -g silage samples were collected, and $90 \mathrm{~mL}$ of sterile phosphate buffer was added to each sample, which yielded a $10^{-1}$ dilution. Next, ten-fold serial dilutions from $10^{-1}$ to $10^{-6}$ were generated and plated. The plates were incubated at $39{ }^{\circ} \mathrm{C}$ for $\mathrm{LAB}$ and $30{ }^{\circ} \mathrm{C}$ for ENT and $\mathrm{CL}$ in anaerobic jars at room temperature for MY. LAB and CL were quantified after $48 \mathrm{~h}$ of growth, ENT after $24 \mathrm{~h}$ of growth, and MY after seven days of growth. Following incubation, colonies were counted using a Quebec colony counter. Plates with between 30 and 300 CFU (colony-forming units) were counted, and the data were $\log 10$ transformed (Quinn, 2005).

The total digestible nutrient (TDN) percentages were calculated using the following equation (Van Soest, 1994): TDN = IVDMD + $(1.25 *$ EE $)-$ ash. IVDMD = in vitro dry matter digestibility; and $\mathrm{EE}=$ ether extract. The IVDMD was estimated using the gas production method following a 48-hour incubation (Maurício et al., 2003).

The results were analyzed using the program Statistical Analysis System (SAS) version 9.1 (2003). Residual normality was tested using the Shapiro-Wilk test
(PROC UNIVARIATE), and variances were compared using orthogonal contrast (PROC GLM) at the 5\% significance level. PROC IML was used to generate vectors for each contrast. When significant, regression equations were fit to the data using PROC REG.

\section{RESULTS AND DISCUSSION}

The variation in effluent production was fit best using a second-order polynomial equation (Table 1). The minimum effluent production value was estimated at $1.17 \mathrm{~kg} \mathrm{t}^{-1}$ GF for $10.61 \%$ grape pomace using the regression equation. Effluent loss during ensiling is directly influenced by the moisture content of the ensiled mass (Balieiro Neto et al., 2009), which may have decreased due to the high grape pomace DM concentration $(50.67 \%)$.

The variation in gas loss also fit best using a second-order polynomial equation $(p<0.05)$ (Table 1$)$. The minimum gas loss value was estimated at $1.19 \% \mathrm{DM}$ for $5.52 \%$ grape pomace.

Total dry matter loss and dry matter recovery are inversely proportional. Both the minimum total dry matter loss value $(1.38 \% \mathrm{DM})$ and maximum dry matter recovery value $(98.63 \% \mathrm{DM})$ were estimated for $5.49 \%$ grape pomace (Table 1). The low total dry matter loss and high dry matter recovery observed indicate good silage preservation. This result may be caused by the dry matter increase ranging from $22.7 \%$ to $29 \%$ due to adding the grape pomace, which contained $50.67 \%$ DM.

We did not observe significant differences $(p>0.05)$ in DM density with different quantities of grape pomace (Table 1). The mean DM density was 486.75 $\mathrm{kg} \mathrm{GF} \mathrm{m}^{-3}$.

The $\mathrm{pH}$ decreased linearly with increasing quantities of grape pomace and varied from $3.96(0 \%$ inclusion) to 3.87 ( $40 \%$ inclusion) (Table 2). Although the $\mathrm{pH}$ varied among treatments, the observed values were within the ideal $\mathrm{pH}$ range for silage (3.6-4.2) suggested by Tomich et al. (2003). However, $\mathrm{pH}$ alone is not sufficient to determine silage quality.

The variation in total nitrogen fit best using a second-order polynomial equation $(p<0.05$; Table 2$)$. The minimum total nitrogen concentration value was estimated at $2.02 \% \mathrm{DM}$ for $29.17 \%$ grape pomace using the regression equation. The nitrogen is generated through nitrogen compound degradation by microorganisms, which changes the crude protein and ammoniacal nitrogen concentrations. 
Table 1: Fermentation loss, dry matter recovery and dry matter density of $C$. procera silage with grape pomace.

\begin{tabular}{|c|c|c|c|c|c|}
\hline \multirow{2}{*}{ Variable } & \multicolumn{4}{|c|}{ Grape pomace added (\%GF) } & \multirow{2}{*}{ SEM } \\
\hline & 0 & 10 & 30 & 40 & \\
\hline Dry matter, \% & 22.7 & 23.1 & 26.9 & 29.0 & 0.68 \\
\hline Effluent loss, $\mathrm{kg} \mathrm{t}^{-1} \mathrm{GF}$ & 1.53 & 1.59 & 1.36 & 5.24 & 0.48 \\
\hline Gas loss, \% DM & 5.35 & 1.67 & 11.7 & 14.4 & 1.32 \\
\hline Total dry matter loss, $\%$ & 5.47 & 2.80 & 11.9 & 14.6 & 1.27 \\
\hline Dry matter recovery, $\%$ & 94.5 & 97.2 & 88.0 & 85.3 & 1.27 \\
\hline Density, kg GF m³ & 485.2 & 485.1 & 484.9 & 491.8 & 1.37 \\
\hline Variable & \multicolumn{4}{|c|}{ Regression equation } & $\mathrm{R}^{2}$ \\
\hline Dry matter, $\%$ & \multicolumn{4}{|c|}{$\hat{Y}=22.50+0.169 x$} & 90.63 \\
\hline Effluent loss, $\mathrm{kg} \mathrm{t}^{-1} \mathrm{GF}$ & \multicolumn{4}{|c|}{$\hat{Y}=1.69-0.0976 x+0.0046 x^{2}$} & 91.83 \\
\hline Gas loss, \% DM & \multicolumn{4}{|c|}{$\hat{Y}=5.57-1.589 x+0.144 x^{2}$} & 67.25 \\
\hline Total dry matter loss, $\%$ & \multicolumn{4}{|c|}{$\hat{Y}=5.71-1.58 x+0.144 x^{2}$} & 67.67 \\
\hline Dry matter recovery, $\%$ & \multicolumn{4}{|c|}{$\hat{Y}=94.28+1.583 x-0.144 x^{2}$} & 67.67 \\
\hline Density, kg GF m³ & \multicolumn{4}{|c|}{$\hat{Y}=486.75$} & - \\
\hline
\end{tabular}

$\mathrm{SEM}=$ standard error of the mean; $\mathrm{R}^{2}$ = coefficient of determination; and GF = green forage.

Table 2: $\mathrm{pH}$, total nitrogen $(\mathrm{TN})$ and ammoniacal nitrogen $\left(\mathrm{N}-\mathrm{NH}_{3}\right)$ concentrations and $\mathrm{N}-\mathrm{NH}_{3} / \mathrm{TN}$ ratio of $C$. procera silage with grape pomace.

\begin{tabular}{cccccccc}
\hline & \multicolumn{9}{c}{ Grape pomace added (\%GF) } & & & \\
\cline { 2 - 5 } Variable & 0 & 10 & 20 & 40 & SEM & RE & $\mathrm{R}^{2}$ \\
\hline $\mathrm{PH}$ & 3.96 & 4.03 & 3.89 & 3.87 & 0.021 & $\hat{\mathrm{Y}}=4.01-0.0038 \mathrm{x}$ & 48.69 \\
$\mathrm{TN}, \% \mathrm{DM}$ & 2.21 & 2.12 & 2.02 & 2.05 & 0.021 & $\hat{\mathrm{Y}}=2.22-0.014 \mathrm{x}+0.00024 \mathrm{x}^{2}$ & 74.32 \\
$\mathrm{~N}-\mathrm{NH}_{3} \%$ & 4.80 & 5.59 & 6.38 & 5.60 & 0.176 & $\hat{\mathrm{Y}}=4.73+0.12 \mathrm{x}-0.002 \mathrm{x}^{2}$ & 76.41 \\
$\mathrm{~N}-\mathrm{NH}_{3} / \mathrm{TN} \%$ & 2.16 & 2.63 & 3.15 & 2.89 & 0.108 & $\hat{\mathrm{Y}}=2.12+0.075 \mathrm{x}-0.00013 \mathrm{x}^{2}$ & 73.34 \\
\hline
\end{tabular}

$\mathrm{SEM}$ = standard error of the mean; $\mathrm{RE}$ = regression equation; $\mathrm{R}^{2}$ = coefficient of determination; and GF = green forage.

The variation in $\mathrm{N}-\mathrm{NH}_{3}$ concentrations $(\% \mathrm{DM})$ also fit best using a second-order polynomial equation. The maximum $\mathrm{N}-\mathrm{NH}_{3}$ concentration was estimated at $6.53 \%$ for $30 \%$ grape pomace using the regression equation. However, low values were observed. The N-NH concentration is related to the quantity of protein degraded during fermentation and, therefore, indicates the protein lost during fermentation. All treatments presented N-NH concentrations below the $10 \%$ threshold established by Mcdonald, Henderson and Heron (1991); higher values indicate intense proteolysis.

The maximum $\mathrm{N}-\mathrm{NH}_{3} / \mathrm{TN}$ ratio was estimated at $3.20 \%$ for $28.85 \%$ grape pomace. In general, the $\mathrm{N}^{-\mathrm{NH}_{3} /}$ $\mathrm{TN}$ values observed herein were low considering the quantity of $\mathrm{N}$ from the degradation of amino acids and other nitrogen compounds and that bacteria from the genus Clostridium spp. was not observed (Table 3), which may have been due to bacterial inhibition during fermentation.

The lactic acid bacteria counts decreased linearly $(p<0.05)$ with increasing levels of grape pomace added to the $C$. procera silage (Table 3). According to McDonald, Henderson and Heron (1991), the number of lactic acid bacteria required to markedly decrease the $\mathrm{pH}$ is approximately $8.0 \log \mathrm{CFU} / \mathrm{g}$ silage.

The $\mathrm{LAB}$ populations varied in a similar manner to the soluble carbohydrate and lactic acid concentrations (Table 4). This observation may be due to the gradual decrease in soluble carbohydrates, limiting LAB growth, 
thus producing less lactic acid. Sá Neto et al. (2013) analyzed corn and sugarcane silages and measured 5.32 and $6.96 \log$ CFU/g silage after 150 days of fermentation. During the silage-stability phase following 40 days of fermentation, the lactic acid bacteria remain active but at lower numbers. Silage preservation depends on lactic acid bacteria activity, which is responsible for decreasing the $\mathrm{pH}$ and inhibiting Clostridium spp growth. Additionally, under anaerobiosis, lactic acid bacteria activity also decreases the number of mold and yeast (Santos; Zanine, 2006).

The mold and yeast counts were affected by adding grape pomace to the $C$. procera silage, and significant differences $(p<0.05)$ among treatments were observed (Table 3). Yeasts may produce high ethanol concentrations in silage (Muck, 2010), which was observed herein because the ethanol concentrations increased with greater yeast populations (Table 4). Dolci et al. (2011) studied corn silage with a bacterial inoculant and reported a mold and yeast count of $6 \log \mathrm{CFU} / \mathrm{g}$ silage, which is similar to the values observed herein without a microbial inoculant.

Enterobacteria and Clostridium spp. were not observed in the silage after the silos were opened. These undesirable microorganisms develop during the first days of fermentation in the ensiled mass; however, LAB lactic acid production decreases the $\mathrm{pH}$ during fermentation, which restricts their growth. The absence of enterobacteria observed herein is consistent with Castro et al. (2006), who evaluated the microbial profile of Tifton 85 grass silage produced with different dry matter concentrations.

The soluble carbohydrate concentrations varied with different levels of grape pomace, and the variation was fit best using a second-order polynomial equation $(p<0.05$; Table 4$)$. The minimum value was estimated at $3.44 \%$ DM for $23.89 \%$ grape pomace. This concentration was lower than the $5 \%$ established by McDonald, Henderson and Heron (1991) as the minimum soluble carbohydrate concentration necessary to ensure good fermentation. The low value may explain the decrease in lactic acid production with grape pomace. Soluble carbohydrate is the main substrate used by microorganisms during the fermentation of ensiled mass and contributes to lactic acid production, which, in turn, increases acidity and preserves the silage (Carvalho et al., 2014).

The ethanol concentrations increased linearly $(p<0.05)$ with increasing quantities of grape pomace with a $633 \%$ total increase between 0 and $40 \%$ grape pomace. This increase may have been due to the epiphytic yeast populations in the grape pomace, which are responsible for wine fermentation and consume silage sugars.

Table 3: Populations of lactic acid bacteria (LAB) and mold and yeast (MY) in C. procera silage with grape pomace.

\begin{tabular}{cccccccc}
\hline \multirow{2}{*}{$\begin{array}{c}\text { Microbial } \\
\text { populations }\end{array}$} & \multicolumn{9}{c}{ Grape pomace added (\%GF) } & & \\
\cline { 2 - 5 } & 0 & 10 & 20 & 40 & SEM & $\hat{Y}=6.437-0.0066 x$ & $R^{2}$ \\
\hline LAB log CFU/g & 6.43 & 6.35 & 6.21 & 5.82 & 0.06 & 95.67 \\
MY log CFU/g & 5.74 & 5.51 & 5.63 & 5.72 & 0.03 & $\hat{Y}=5.74-0.05 x+0.003 x^{2}-0.00005 x^{3}$ & 51.30 \\
\hline
\end{tabular}

$\mathrm{SEM}$ = standard error of the mean; RE = regression equation; $\mathrm{R}^{2}$ = coefficient of determination; CFU/g: Colony forming unit per gram silage; log: Logarithm; and GF = green forage.

Table 4: Soluble carbohydrate, ethanol and organic acid (lactic, acetic, propionic and butyric acids) concentrations in C. procera silage with grape pomace.

\begin{tabular}{|c|c|c|c|c|c|c|c|}
\hline \multirow{2}{*}{ Variable (\% DM) } & \multicolumn{4}{|c|}{ Grape pomace added (\%GF) } & \multirow[b]{2}{*}{ SEM } & \multirow[b]{2}{*}{$\mathrm{RE}$} & \multirow[b]{2}{*}{$\mathrm{R}^{2}$} \\
\hline & 0 & 10 & 20 & 40 & & & \\
\hline Soluble carbohydrate & 8.64 & 5.00 & 3.71 & 5.99 & 0.50 & $\hat{Y}=8.58-0.43 x+0.009 x^{2}$ & 85.80 \\
\hline Ethanol & 0.45 & 0.92 & 1.15 & 3.30 & 0.28 & $\hat{Y}=0.21+0.07125 x$ & 91.61 \\
\hline Lactic acid & 5.30 & 2.98 & 2.21 & 1.94 & 0.38 & $\hat{Y}=5.21-0.236 x+0.0039 x^{2}$ & 78.69 \\
\hline Acetic acid & 1.74 & 2.97 & 2.88 & 2.28 & 0.14 & $\hat{Y}=1.84+0.11 x-0.0025 x^{2}$ & 67.81 \\
\hline Propionic acid & 0.08 & 0.66 & 0.81 & 0.60 & 0.07 & $\hat{Y}=0.10+0.063 x-0.0012 x^{2}$ & 94.19 \\
\hline Butyric acid & 0.003 & 0.006 & 0.011 & 0.010 & 0.0009 & $\hat{Y}=0.003+0.00057 x-0.000009 x^{2}$ & 60.92 \\
\hline
\end{tabular}

$\mathrm{SEM}$ = standard error of the mean; RE = regression equation; $\mathrm{R}^{2}=$ coefficient of determination; and $\mathrm{GF}=$ green forage. 
Adding grape pomace yielded low organic acid concentrations and decreased the lactic acid in all treatments. The variation in lactic acid concentration fit best using a second-order polynomial equation $(p<0.05)$, and the minimum value was estimated at $1.6 \% \mathrm{DM}$ for $30.26 \%$ grape pomace using the regression equation. Although all organic acids decrease the silage $\mathrm{pH}$, lactic acid is the main compound responsible for the $\mathrm{pH}$ decrease and preservation of the ensiled mass (Calabro et al., 2005). The variation in the lactic acid produced during fermentation is consistent with the lactic acid bacteria counts, which decreased with the quantity of grape pomace added to the silage (Table 3 ).

Acetic acid concentrations, which are associated with enterobacteria and heterofermentative lactic acid bacteria activity, increased with increasing quantities of grape pomace up to $22 \%$, for which we approximated a maximum value of $3.05 \%$ DM. Acetic and butyric acid concentrations in silage are related to a higher final $\mathrm{pH}$, which was not observed herein (Table 2). In addition, fermentation by these microorganisms results in higher losses of dry matter and energy from the ensiled material (Queiroz et al., 2015). The variation in propionic acid concentrations was best fit using a second-order polynomial equation $(p<0.05)$; the maximum value was estimated as $0.93 \%$ DM for $26.25 \%$ grape pomace. Propionic acid is the main gluconeogenic precursor in ruminants and is responsible for approximately $60 \%$ of the glucose produced, which occurs in the liver (Caldeira, 2005).

The maximum butyric acid concentration was estimated as $0.012 \% \mathrm{DM}$, for $31.67 \%$ grape pomace, which is within the recommended values for good quality silage. Tomich et al. (2003) recommended a maximum butyric acid concentration of $0.09 \%$ DM. Because high soluble carbohydrate concentrations in silage favor lactic and alcoholic fermentation, increases in butyric acid concentrations are not expected (Silva et al., 2008). The low values observed for butyric acid may be related to the low ammoniacal nitrogen in the silage, indicating low Clostridium spp. activity and high silage quality, which were confirmed by the absence of Clostridium spp.

High TDN percentages were observed, which are most likely due to the DM digestibility coefficients because the two variables were positively correlated (Figure 1). The TDN variation fit best to a second-order polynomial equation $(p<0.05)$; the maximum value was estimated at $82.95 \%$ DM for $3.5 \%$ grape pomace using the regression equation, which showed a decrease for higher quantities of grape pomace. Pereira et al. (2010) evaluated the chemical composition and energy values of forage plants and agroindustrial byproducts in northeast Brazil and reported $63.91 \%$ TDN for fresh $C$. procera. These values are similar to the values reported by Cândido et al. (2011) (59.01\% TDN), who studied dairy goats fed with $C$. procera hay.

The IVDMD decreased linearly $(p<0.05)$ with increasing quantities of grape pomace, varying between 85.96 and $76.84 \% \mathrm{DM}$ for 0 and $40 \%$ grape pomace, respectively. Although the IVDMD coefficients decreased linearly, the values were quite high. Cruz et al. (2007) evaluated the digestibility of fresh $C$. procera and calculated a mean IVDMD of $80.1 \%$. Lima et al. (2005) evaluated the in vivo digestibility of $C$. procera silage following 12 hours of pre-drying and calculated a dry matter digestibility coefficient of $71.23 \%$.

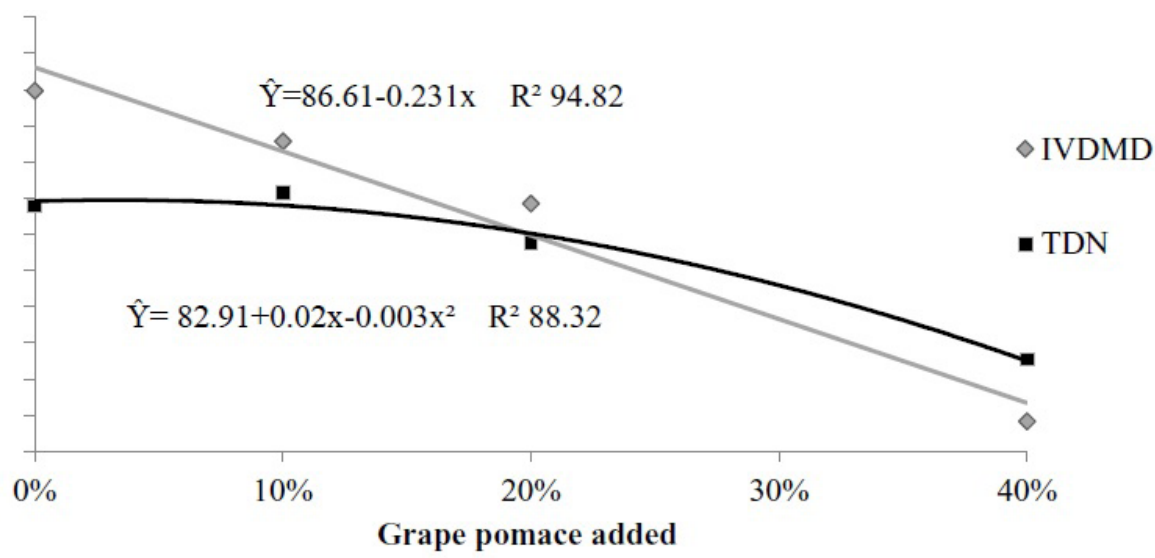

Figure 1: TDN percentage and IVDMD of $C$. procera silage with different quantities of grape pomace. 


\section{CONCLUSION}

Wilted $C$. procera may be used as silage the addition of grape pomace diminished the fermentation characteristics, indicating that $C$. procera silage does not require additives or ensiling with grape pomace.

\section{REFERENCES}

BALIEIRO NETO, G. et. al. Perdas fermentativas e estabilidade aeróbia de silagens de cana-de-açúcar aditivadas com cal virgem. Revista Brasileira de Saúde e Produção Animal. 10(1):24-33, 2009.

BARROSO, D. D. et al. Resíduo desidratado de vitivinícolas associado a diferentes fontes energéticas na alimentação de ovinos: Consumo e digestibilidade aparente. Ciência e Agrotecnologia. 30(4):767-773, 2006.

CALABRO, S. et al. In vitro fermentation kinetics of fresh and dried silage. Animal Feed Science and Technology. 123:29-137, 2005.

CALDEIRA, R. M. Monitorização da adequação do plano alimentar e do estado nutricional em ovelhas. Revista Portuguesa de Ciências Veterinárias. 100(555-556):125139, 2005.

CÂNDIDO, E. P. et al. Comportamento ingestivo de cabras de aptidão leiteira alimentadas com feno de flor de seda. Revista Agropecuária Técnica. 32:145-151, 2011.

CARVALHO, F. A. L. et al. Características fermentativas na ensilagem de cana-de-açúcar com maniçoba. Ciência Rural. 44:2078-2083, 2014.

CASTRO NETO, A. G. et al. Parâmetros de fermentação de silagens de cana-de-açucar submetidas a diferentes tratamentos. Arquivo Brasileiro de Medicina Veterinária e Zootecnia. 60(5):1150-1156, 2008.

CASTRO, F. G. F. et al. Perfil microbiológico, parâmetros físicos e estabilidade aeróbia de silagens de capim-tifton 85 (Cynodon sp.) confeccionadas com distintas concentrações de matéria seca e aplicação de aditivos. Revista Brasileira de Zootecnia. 35(2):358-371, 2006.

COSTA, R. G. et al. Perspectivas de utilização da flor-de-seda (Calotropis procera) na produção animal. Revista Caatinga. 22(1):1-9, 2009.

CRUZ, S. E. S. B. S. et al. Caracterização dos taninos condensados das espécies maniçoba (Manihot pseudoglazovii), flor-deseda (Calotropis procera), feijão-bravo (Capparis flexuosa, $L$ ) e jureminha (Desmanthus virgatus). Arquivo Brasileiro de Medicina Veterinária Zootecnia. 59:1038-1044, 2007.
DOLCl, P. et al. Microbial dynamics during aerobic exposure of corn silage stored under oxygen barrier or polyethylene films. Applied and Environmental Microbiology. 77(21):7499-7507, 2011.

DUBOIS, M. et al. Colorimetric method for determination of sugars and related substances. Analytical Chemistry. 28(3):350, 1956.

JOBIM, C. C. et al. Avanços metodológicos na avaliação da qualidade da forragem conservada. Revista Brasileira de Zootecnia. 36:101-120, 2007.

LIMA, B. A. et al. Estudos preliminares da Calotropis procera S. W. na dieta de ovinos. Agropecuária Científica no SemiÁrido. 01:15-24, 2005.

MAURÍCIO, R. M. et al. Potencial da técnica in vitro semiautomática de produção de gás para avaliação de silagens de sorgo [Sorghum bicolor (L.) Moench]. Revista Brasileira de Zootecnia. 32(4):1013-1020, 2003.

McDONALD, P.; HENDERSON, A. R.; HERON, S. J. E. The biochemistry of silage. Marlow: Chalcomb Publications, 2. ed. 1991. 340p.

MELLO, M. M. et al. Estudo fitoquímico da Calotropis procera Ait., sua utilização na alimentação de caprinos: Efeitos clínicos e bioquímicos séricos. Belo Horizonte, MG. Revista Brasileira de Saúde e Produção Animal. 2(1):1520, 2001.

MUCK, R. E. Silage microbiology and its control through additives. Revista Brasileira de Zootecnia. 39:183-191, 2010.

NATIONAL RESEARCH COUNCIL - NRC. Nutritional ecology of the ruminant. Ithaca: 2.ed. Cornell University Press, 1994. 476p.

PALMQUIST, D.; CONRAD, H. Origin of plasma fatty acids in lactating cows fed high fat diets. Journal of Dairy Science. 54:1025-1033, 1971.

PEREIRA, E. S. et al. Determinação das frações proteicas e de carboidratos e estimativa do valor energético de forrageiras e subprodutos da agroindústria produzidos no Nordeste Brasileiro. Semina: Ciências Agrárias. 31:1079-1094, 2010.

QUEIROZ, M. A. A. et al. Características fermentativas e bromatológicas de silagens de cana-de-açúcar com taboa. Ciência Rural. (45):136-141, 2015.

QUINN, P. J. Microbiologia Veterinária e Doenças Infecciosas. Porto Alegre: Artmed, 2005. 470p. 
SÁ NETO, A. et al. Silagem de milho ou de cana-de-açúcar com Lactobacillus buchneri exclusivamente ou em associação com L.plantarum. Pesquisa Agropecuária Brasileira. 48(5):528-535, 2013.

SANTOS, E. M.; ZANINE, A. M. Silagem de gramíneas tropicais. Colloquium Agrariae. 2(1):32-45, 2006.

SAS INSTITUTE. SAS/STAT: Guide for personal computer; version 13. Cary, p. 235, 2003.

SCHMIDT, P. et al. Aditivos químicos e biológicos na ensilagem de cana-de-açúcar. 1. Composição química das silagens, ingestão, digestibilidade e comportamento ingestivo. Revista Brasileira de Zootecnia. 36(5):1666-1675, 2007.
SILVA, D. J.; QUEIROZ, A. C. Análise de Alimentos (métodos químicos e biológicos). 3.ed. Viçosa: Imprensa Universitária, 2002. 235p.

SILVA, E. J. A. et al. Efeitos do teor de carboidratos solúveis sobre as características da silagem de cana-de-açucar. Revista Brasileira de Zootecnia. 37(8):1375-1382, 2008.

TOMICH, T. R. et al. Características químicas para avaliação do processo fermentativo de silagens: Uma proposta para qualificação da fermentação. (Documentos, 57), Corumbá: Embrapa Pantanal. 2003. 20p.

VAN SOEST, P. J. Nutritional ecology of the ruminant. Ithaca: 2.ed. Cornell University Press, 476p. 1994. 